\title{
Communication Accommodation Theory: A Brief Review of the Literature
}

\section{Ali Elhami*}

Universidad Autónoma de Madrid (UAM), Spain

DOI: 1 10.36348/jaep.2020.v04i05.002 $\quad$ | Received: 22.04.2020 | Accepted: 02.05.2020 | Published: 08.05 .2020

*Corresponding author: Ali Elhami

Email: a.elhami.ali@gmail.com

\section{Abstract}

Studies on Communication Accommodation Theory has advanced rapidly in recent years. Communication is an important part of human life and from the beginning of human history, people have always tried to communicate together and to understand the others and make themselves understood. This paper aims to have a brief review on the notion "Communication Accommodation Theory" (CAT), which is an important aspect of different sciences (e.g., Linguistics, sociology, sociolinguistics, and psychology). The concept of Communication Accommodation is used in all people's social life, for instance, between mother and child, teacher and student, reporter and listener, doctor and patient, and immigrants (newcomers) and citizens, however, this review helps us to have a better understanding through CAT.

Keywords: Communication Accommodation Theory, Convergence, Divergence, Maintenance, Over-Accommodation, Under-Accommodation.

Copyright @ 2020: This is an open-access article distributed under the terms of the Creative Commons Attribution license which permits unrestricted use, distribution, and reproduction in any medium for non-commercial use (NonCommercial, or CC-BY-NC) provided the original author and sources are credited.

\section{INTRODUCTION}

Generally speaking people in all parts of the world and all context talk together or write for each other. By taking a quick glance around ourselves we recognize all people for talking together consciously or unconsciously change the way of their communication which can be either verbal or nonverbal. For this matter, there are numerous examples, such as a doctor's office, imagine a physician and his/her patient are having a conversation about the patient's symptoms, in this contexts, some doctor use specialized vocabularies and do not try to facilitate the conversation for the patient to understand well, and the others use the vocabularies to be understandable for the patient who does not have any idea about disease.

Another context that is very touchable for almost all people is related to teacher and student(s) communication, when teachers in language classes, for example, use easier structure and vocabularies based on the level of students they try to facilitate learning for the learners. Sometimes we need to speak more formal or less formal, sometimes slower or faster, and many other examples that every day all human beings use in their daily speech.

In recent decades with the increasing number of migration and intercultural contact studies on CAT, convergence, and divergence, and also reasons people use these strategies to facilitate or accentuate their communication in different situations has become a focal center of interest among researchers. When an immigrant enters a country to start their new life might face different problems that need to tackle. One of the biggest problems many immigrants face is the language of the target country which can be either verbally or nonverbally. For example, an immigrant in Spain form an Asian country who does not have any idea about Spanish language, gestures, cultures, customs, etc., may have problem communicating with native people, and this person for having contact with the native speakers needs to learn their language, in this way some native speakers understand their lack of language knowledge and simplify their speech (consciously or unconsciously) they may use more body language, easier vocabularies, and grammatical structures, slow their speech, whereas the other groups due to different reasons act oppositely, speak faster, use more complicated structures and vocabularies. This matter does not happen only for immigrants, it may happen in our daily communication, on TV shows, radio, even when different generations talk together may have a problem with understanding each other. Based on this fact, CAT is an important notion which in this paper I focus on its definition and different strategies people employ to communicate with each other. 


\section{Communication Accommodation Theory}

Awareness of communication accommodation theory (CAT) is not recent, in the 1970s it was first presented [1] as speech accommodation theory (SAT) Giles [1] considered that while people talking to the others change their accent to be more similar to their interlocutors. Six years later, Giles and Smith [2] report that, besides accent, speakers change their speech rate, pronunciation, utterance length, and pauses. However, people try to be accepted or understood by the others by adjusting their speech to others. In a follow-up study, Putman and Street [3] observed the trying of interviewees for adjusting their speech to make themselves sound likable for interviewers.

Bandura [4] noted that social learning and imitation maybe are two reasons for adjustment. By the same token, in a recent study, Dragojevic et al. [5] and, Gasiorek \& Giles [6] point out that, people change their speech rate, pitch, volume, lexical choices, Syntax and even topic to be more or (less) similar to each other's, and also to facilitate and improve or even to hinder social relations and interaction [7]. Later, in this theory, speech changed to communication [8]. In this area, Gasiorek \& Giles [9] defines communication with admirable brevity and clarity as a social tool; to make positive impression [7, 10], or negative impression, to influence others, and decrease the social distance [10] and to achieve their social goals $[11,12]$.

By drawing on the concept of CAT, Gallois, Ogay, and Giles [13] believe that it can happen while fasting speech rate, or/and making accent more standard. As it included non-linguistic aspects apart from speech and while interacting, people consciously or unconsciously adjust their communication to each other [14]. For example, when we talk to elderly people, louder our voice, or when parents talk to children use easier vocabularies and grammatical structures. This adjustment is repeated in other different settings, such as immigrants who move to a new society and try to adjust their communication to the target society or even when target society speakers try to accommodate their communication to the immigrants.

In a related study of CAT, four principles of communication accommodation have been considered [15]. Gasiorek and Giles [16] elaborate those four principles as firstly, when they try to have positive face and feeling or even when they look for a common social identity, secondly, when they are looking for the interlocutor(s) satisfaction and comprehension, therefore in the first and second the individuals will accommodate, whereas in the third principle, in which they try to show their dissatisfaction or disrespect to the interlocutor(s) and the fourth one in which they try to show their negative intention toward interlocutor(s), they will nonaccommodate.
A broader perspective has been adopted by Giles $[17,18]$ who argues that CAT is a very important theory of communication, because it merges intergroup and interpersonal contact and it focuses on both intergroup and interpersonal interactions [18, 19, 7]. CAT is an interpersonal and intergroup theory that explains the process of adjustment of individuals to their both communicative and social goals [20]. The relationship between intergroup and interpersonal mediates and improves through communication [19] which helps to foster communication between different ethnic groups [17], second language acquisition [21] and communication between different generations [8]. In the following section, we need to consider the way and the reasons people adjust their communication.

\section{Affective function Vs. Cognitive function}

People employ different strategies to adjust themselves to their interlocutors. And those strategies refer to their goals and needs [22]. Generally, the CAT provides three types of adjustment. Convergence, divergence, and maintenance. Before proceeding further, I need to define two functions of adjustment which is classified based on Giles, Scherer, and Taylor [23] "affective function and cognitive function", the former is related to social distance and identity; related to this Keblusek et al. [24] imply that increasing or decreasing social distance is the result of accommodation between intergroup members and outgroup members. Indeed, speakers accommodate their communication behavior when they need to decrease the social distance and also when wish to join the speaker(s) $[7,25]$. Due to effective function people try to be more similar and likable by assimilating or even to highlight dissimilarities and amplify their sense of identity [7]. Relatively, about affective function Giles and Gasiorek [26] point out that "a number of more specific social effects of accommodation have been put forward, among them identifying or appearing similar to others, maintaining face, maintain a relationship and maintain interpersonal control as it relates to power or status differentials" (p.5). However, the latter is related to comprehension of the communication; which can be either positive to increase the similarities (convergence) or negative to increase the dissimilarities (divergence) [7]. Likewise, Giles [27] point out that accommodation is a mean for comprehension between intergroup and outgroup. Slowing down or accelerating the speed of speaking is a good example of increasing or decreasing comprehension. In a broader view, to fulfill affective and cognitive functions there are different ways of accommodation strategies $[28,6]$. Firstly, when people focus on productive language of interlocutors and adjust verbally and non-verbally to them $[29,26,14]$ in contrast, another type is related to comprehensive ability of the interlocutors, in which people decrease the speech length, or use simpler vocabularies or even speak louder and more clear, and the third type is related to the need, which means people focus on 
interlocutors' need and chose the topic related to their need and interest, the forth, when the focus is on making relationship while interacting, for reminding their relative status to the interlocutor [14]. The fifth, when others' feeling is important, to make the communication comfortable and secure, people use emotional expressions [30]. Commenting on these five strategies, Dragojevic et al. [6] write that, speakers can use more than one strategy synchronously. When people use simpler vocabularies and grammatical rules for better understanding and at the same time for reminding the social position [6] is a good illustration of using two strategies synchronously.

\section{Convergence, Divergence, and Maintenance}

In Communication Accommodation Theory (CAT) the main focus is based on three types of adjustments, convergence, divergence and maintenance [7]. This view is supported by Dragojevic et al. [14] who believe that these adjustments (convergence and divergence) can be either unconscious and automatic or conscious, and also they remind us that, "CAT seeks to explain and predict such communication adjustment, and how others in an interaction perceive, evaluate, and respond to them" (p.1) [14].

The term, convergence is defined as trying of communicators to decrease the differences [31, 32] at linguistic and psychological level [8] to be more similar to the behavior of the interlocutors $[8,7,6]$ more likable to the conversational partner [7] and to seek for social approval $[13,11]$ and to be understood better. For instance, younger people in communication speak louder or making more examples to be understood by elderly people [15]. Latterly, scholars commence studying on convergence and online environments [16] For example, in a study, conducted by [33], shows that, Twitter users usually converge their Tweets linguistically. For example, the politicians from different countries try to write their texts on tweeter or other social Media in English to be more understandable for all nations, or even some of them use the language of the country they aim to send their message to. There is a large number of published studies $[34,6]$ that describe, convergence is a strategy to adapt to each other's not only verbally, but also nonverbally, such as speech rate, accent, pitch, gestures, and length of the speech. In the same way, Giles and Soliz [25] argue that convergence may happen through different communicative dimensions such as changing the topic or switching to another dialect. An example of this is the study carried out by Coupland [28] in which a travel agent for matching to the different Welsh clients, changed her pronunciation. And in a more recent study, Dragojevic et al. [14] observe that, in an interaction between young people and the elderly, usually younger people adjust (converge) their communicative behaviors for counterbalancing.
On the other hand, unlike convergence which is a type of adjustment for facilitating and showing more similarities between communicators, divergence is to highlight and emphasize the differences [27], and to increase the differences between interlocutors [35]. On the other hand, those who diverge want to be distinguished from the others and they try to inculcate who they are in others' minds [36]. Dragojevic et al. [14] define divergence as "adjusting communicative behaviors to accentuate verbal and non-verbal differences with others, to appear more dissimilarity" (p. 8). As noted by Palomares et al. [37] increasing social distance can be a reason for divergence. The divergence adjustment has been exemplified in an earlier study between Welsh participants and English speakers by Giles et al. [23], they found that Welsh participants accentuate their accent and used Welsh phrases and vocabularies and they try to show their Welsh identity when English speakers defined Welsh as a fading language. Generally, convergence provokes a positive response whereas, divergence provokes a negative response [23]. In an earlier study investigating divergence adjustment, Street and Giles [38] remind us that divergence does not always act as obstacle, in some situations, it is a way to ease comprehension, the evidence of divergence as facilitating comprehension can be seen in the case of a bilingual who may act like she or he has problems over remembering or finding words to remind the interlocutor any malfunction in linguistic or cultural interaction is because of foreignness. Or even divergence can be a goal for the interlocutor to converge his or her speech pattern [38] in the similar example, the bilingual by pretending to have problems for remembering words may motivate interlocutor to converge his or her speech.

The term maintenance which is similar to divergence [7] or it is a form of divergence [27] has come to be used to refer to remaining in his or her level of communication and not adjusting to the others [39], in other words, Gasiorek \& Giles [9] imply that maintenance is "the Absence of accommodation adjustment by individuals, that is, maintaining their 'default' way of communicating without taking into account the characteristics of their fellow interactants" (p.6). Interestingly, these two strategies (divergence and maintenance) can be evaluated unpropitious form the point of view interlocutor, and propitious from the point of view of observers who derive it from values of group membership [7]. In a study in Montreal, a female asked a direction in English and French, when she asked in French almost half of the Anglophone pedestrians answered in English; actually they remained in their default language [40]

Gallois and Giles [19] argue that convergence and divergence can appear in different distinctions. In this regard, Dragojevic et al. [14] categorized those distinctions as, upward and downward, short term and long term, symmetrical and asymmetrical, full and 
partial, and unimodal and multimodal. For Giles and Powesland [41] upward and downward adjustment (convergence, divergence) are related to social values. Upward convergence is moving or shifting toward the more prominent variety of speech [6] or in another word, adopting to the communication behavior which is the more socially accepted [25], conversely, downward convergence is shifting or moving to the less prominent variety of speech [6]. An example of this study carried out by Willemyns, Gallois, Callan, and Pittan [15] in which they define upward convergence as people who speak nonstandard English, shift to Standard English while interacting Standard English speakers, on the other hand, when Standard English speakers adapt their accent to nonstandard English speakers is known as downward convergence. Besides, Dragojevic et al. [6] mention that in the same situation when nonstandard English speakers highlight their accent in interacting with Standard English speakers is an example of downward divergence. Whereas, upward divergence is when Standard English speakers highlight and accentuate their accent in interacting with nonstandard English speakers.

Another form of adjustment is short-term/longterm which is related to the duration of adjustment. Dragojevic et al. [6] believe that adjustment can live shortly toward a particular style which is known as short-term adjustment whereas sometimes it lives long and communicator repeats it overtime that is known as the long-term adjustment. Pardo et al. [42] observe that mutual convergence increases over an academic year among male roommates. This study is a good example of long-term convergence,

Dragojevic et al. [14] believe that accommodation can be either symmetrical or asymmetrical. The former means when both communicators adjust their speech (convergence or divergence), in contrast, the latter is related to when one of the communicators has a desire for communication [43]. A study which was conducted by Nelson, Dickson, \& Hargie [44] is a good example of symmetrical adjustment, in their study which was in Northern Ireland between Catholic and Protestant children, they found that both groups (Catholics and Protestant) avoid some topics such as politics and religion in interacting together. Another study by Van den Berg [45] is a good example of asymmetric adjustment; he observed that in Taiwan, sellers converge more than shoppers. Also, in a more recent study related to asymmetrical adjustment, Namy, Nygaard, \& Sauerteig [46] find out that, in the interaction between males and females, usually females converge more than males.

Adjustment can be either full or partial. Street \& Giles [38] argues that, when a speaker normally uses 100 words per minute, and his or her interlocutor uses 200 words, he or she tries to reach the interlocutor's speed, if speaker can reach 200 words per minute it is a definition of full convergence and if for example reaches 150 words per minute, it is partial convergence.

Now we move to unimodal and multimodal adjustment. Unimodal, in which people shift or change only one aspect of communication such as accent, in contrast, multimodal that refers to shifting or changing more than one aspect of communication such as, accent, gesture, and posture [6]. for instance, in a study by Bourhis and Giles [23] which was mentioned above, when Welsh participants, only focusing on their Welsh accent is an example of unimodal adjustment, whereas when they focus on accentuating their accent, phrases, new vocabularies is an example of multimodal adjustment. Communicators may use both convergence and divergence in one talk [14], which means in a talk they may converge in some topics and diverge in other topics. For example, Bilous and Krauss [47] observed that women while talking to men converge in their pauses, utterance length, and interruption, but diverge on laughter.

\section{Ways of adjustment in communication}

In communication, people use different strategies to converge or diverge with each other (e.g. long term-short term, unimodal-multimodal, or fullpartial). To wit, communicators try to positively or negatively adjust themselves (verbally and nonverbally) to the interlocutor(s) due to different reasons, such as being accepted by the interlocutor(s) (convergence) or trying to prove their differences (divergence) in language, identity, social background, etc. In this part, the focus is on the ways people employ (consciously or unconsciously) to take advantage of different strategies to adjust their communication. Gasiorek [6] provides ten ways people use to adjust their communication related to long term-short term, unimodal-multimodal, full-partial, etc. these ten classifications are, response matching, code-switching, audience design, recipient design, grounding, mimicry, linguistic style matching, constructivism, discrepancy arousal theory, and interaction adaptation theory [43].

This shows a need to be explicit about exactly what is meant by the term "response matching". In an earlier study, Argyle [48] conceded response matching to communication adaptation, also added that response matching takes place in both verbal and non-verbal behaviors (e.g. utterance length, words, gesture, and posture). Whereas, code-switching (CS) which is defined as using two or more languages or dialects for communicating to bilinguals, multilinguals, bidialectals or multi-dialectals $[49,50]$, different studies show that CS is more an unconscious process [51,6]. It is necessary here to clarify exactly what is meant by "Audience design". The term "Audience design" which is a sociolinguistic model was introduced by Bell [52]. In this model, speakers need to make their speech understandable to show solidarity. More specifically, in 
a daily conversation, speakers make sentences or expressions that are understandable for a specific audience [50]. Gasiorek [9] believes that it is taking others in to account to make communication and also the topic and content are needed to be adapted. Such as radio broadcasters [52]. In contrast, recipient design is when "speakers design talk with knowledge of the addressee or recipient in mind" [34]. Also, she argues that this type of adjustment is for having effective communication [34].

The term "Grounding" refers to collecting mutual knowledge, beliefs, and assumption for well understanding each other $[53,54]$. Communicators need to ground firstly to continue the interaction $[55,56,53$, $57,54]$ by using continuers viz yea, uh, or huh [58] or answering the questions or echoic repeats [59] or having reaction such as oh, gosh [60] and secondly to make certain about the interlocutors that have understood them [55] by getting confirmation before continuing the conversation $[61,56]$. In contrast, mimicry is defined as, imitating the verbal and/or nonverbal behavior of others without conscious awareness [62]. Besides, Gasiorek [34] mentions that mimicry helps understand the emotions between communicators. The next term, Linguistic style matching (LSM) [63, 64] is defined as the verbal mimicry [6] which facilitate language understanding [22], however, Niederhoffer and Pennebaker [64] believe that Language style matching (LSM) is a type of communication adjustment from the perspective of imitating interlocutor. Similarly, Pennebaker [65] argues that speakers will have a common understanding of their conversation while both of them converge in an aspect of word choice. From the aspect of linguistic accommodation (subjective and objective) which will be reviewed later, Romero et al. [66] imply that "LSM may result in more positive evaluations because it signals that the matcher takes the opponent's perspective and is therefore in a better position to be persuasive" (p.5). This view is supported by Pennebaker [65] who found that learners who match their language to their teacher achieve higher grades and also perform better than the others.

The next notion is called Discrepancy Arousal Theory (DAT), it is believed that adjustment in interaction follows changes in cognitive arousal, which are the result of discrepancies between expectations and reality [6]. In this theory, small changes are known as positive and converge response, whereas large ones are called negative and diverge response [6]. The last one, Interaction Adaptation Theory (IAT) [67], in which communication behavior can be both convergence and divergence

Burgoon and Ebesu Hubbard [68] note that the reason communicators use mimicry or code-switching is to fulfill their needs and also for comfort, compared with people who take advantage of mimicry, codeswitching, and IAT those who use other ways (e.g. recipient design, grounding, linguistic style matching) adjust to facilitate the communication and interaction [6].

\section{Linguistic accommodation vs. psychological accommodation}

As eluded above, there are different strategies (convergence, divergence, and maintenance) people employ for adjusting their communication with each other. But the reason(s) of using those strategies is still debatable. In general, accommodation is classified into two types, linguistic accommodation which focuses on speech behavior which we will deal with later, and psychological accommodation which focuses on motivation to converge or diverge [58]. Communicative response and evaluation are important functions of motives that can be inferred from speakers' adjustment [20]. Since communicative adjustment considered as positively motivated, interlocutor evaluates and behaves positively, and while it considered as negatively motivated, interlocutor evaluates and behaves negatively [20], but how to interpret the others ${ }^{\text {ee }}$ behavior is a longitudinal topic among scholars [69, 70]. A recent systematic literature review on motivation and adjustment concludes that the interference people make about motive is automatic [71, 72].

It is salient to imply the influence of motivation toward communication adjustment. Motivation in accommodation is categorized into two types [7], affective motives and cognitive motives. The former, not only aims to manage the social distance, but also concerns about identity, in this type of motivation, people try to gain social approval of the interlocutor by increasing the interpersonal similarities in communication, in contrast, the latter, aims to ease the comprehension $[14,7]$.

The affective motive is playing an important role in communication adjustment. Dragojevic et al. [14] elaborate the notion of affective motive in different adjustment strategies (convergence, divergence, and maintenance). They believe that when people try to adjust (convergence) their communication to be similar to the interlocutor and to be socially approved, and when they adjust their accent or dialect they want to show the interlocutor(s) that they belong the same group, in contrast, sometimes they want to highlight distinctiveness (convergence or maintenance) with the interlocutor(s) to reinforce their social identity [14]. Besides, affective motive which is concerned about identity, cognitive motive concerns about facilitating comprehension [58]. Speakers can adjust their communication to more or less comprehensible. Convergence often increases communicative effectiveness, predictability, speakers' attractiveness, and mutual understanding, and decreases interpersonal anxiety and uncertainty [14]. For instance, some physicians to facilitate the conversation [22] and having 
better comprehension try to use more common terms such as heart attach instead of specific medical terms such as Cardiac arrest [14]. Communication. Speakers may also diverge through communication for encouraging the interlocutor to uses more comprehensible terms. For instance, someone slows down his or her speech rate to encourage the interlocutor to speak slower [14].

On the other hand, linguistic accommodation can be classified into objective and subjective [58, 7]. Objective accommodation has come to be used to refer to perceivable change of behavior either positively (convergence) or negatively (divergence) [7] such as changing the volume, pitch and speed of speaking [43], in contradistinction to objective accommodation, subjective accommodation refers to the feeling and perception of the individual of either interlocutor(s) or their behavior [73, 7]. To clarify, Gallois, Ogay, and Giles [7] imply that "While speakers' linguistic shifts can objectively be described as diverging (or converging), speakers may believe that they are converging (or diverging)" (p. 127). This view is supported by Gilles [27] who implies that in CAT the crucial factor is recipient subjective evaluation since the response is the result of his/her evaluation.

\section{The negative side of the CAT}

The taxonomies about communication accommodation theory, which have hitherto been explained were, long-term and short-term, unimodal and multimodal, and symmetrical, asymmetrical, full and partial, and upwards and downward which are related to convergence and divergence adjustment. From the aspect of subjective accommodation, communication is accommodative to being perceived facilitate and appropriate [39] otherwise it considers as nonaccommodative $[7,5]$. In the other words, the negative side of accommodation which is defined as "communicative behaviors that are inappropriately adjusted for the participants in an interaction" [26] is called nonaccommodation which is divided into two categories [20] that both have negative effect on international communication and positive interaction, to wit, they hinder increasing the social distance. Overaccommodation (over-adjustment) and underaccommodation [14] which Giles [13] believes that they (over accommodation and under accommodation) are a form of divergence. When speakers for having a successful interaction exceed the level of needed adjustment in communication over-accommodation occurs [16, 25]. The behavior of the younger generation toward elderlies is a good example to clarify the notion of over-accommodation. Younger people toward elderlies sometimes try to over-adjust by unnecessary repetition, exaggerated intonation [14], being more polite or speak louder [25]. While, underaccommodation is defined as not trying enough to execute a communication behavior that is needed for the interlocutor [26], also it refers to failing in topic selection for both communicators to become involved in a reciprocated conversation [13]. For example, elderly and younger people usually fail in communication, because elderlies prefer to talk about their ailment or topic that is not engaging for younger adults [13]. Indeed under and over accommodation evaluate as an inappropriate form of accommodation [16] also in their study they found that over the accommodation is evaluated less negatively than underaccommodation [16]. Commenting on nonaccommodation, Gasiorek and Giles [16] emphasize that non-accommodation is the result of a desire for increasing social distance or/and to make comprehension difficult. A broader perspective has been adopted by Gasiorek and Giles [20] who argue that "nonaccommodation is defined as communication that is not adjusted appropriately for at least one interactant" (p.2). Gasiorek [27] believes that nonaccommodation can be either intentional or unintentional. Intentional nonaccommodation occurs when speakers try, others do not understand what they say, and conversely, unintentional non-accommodation which can be the result of dissimilarities in cultural values [6], it happens when communicators do not pay attention to the needs of the interlocutor(s) [20] or misunderstand the needs or knowledge of their interlocutor. In this situation, aspects of communication (e.g. topic, vocabularies, grammatical rules, gesture, etc.), maybe inadvertently employed wrong and as a result, interlocutor does not understand the speakers intend. In the same vein, Hewett, Watson, \& Gallois [74] believe that misunderstanding and dissatisfaction are the results of nonaccommodation. Also, Gasiorek [18] points out that, in this situation, the social distance will increase.

This article has reviewed the literature of CAT and the Convergence, Divergence, and maintenance of Communication accommodation, and different strategies people use to converge or diverge which some of them are long term/ short term, unimodal/ multimodal, and full/ partial, and based on them, then focused on the ways people adjust their communication (e.g., response matching, code-switching, audience design, and mimicry cognitive and also concisely reviewed the affective and cognitive functions of accommodation theory. All of them re related to people's communication and contact, which are playing a prime role in intercultural relations, intergroup contact, integration, and assimilation and also may lower (if convergence happens) or hoist (is divergence or maintenance happen) social and psychological distance.

\section{REFERENCES}

1. Giles, H. (1973). Accent mobility: A model and some data. Anthropological Linguistics, 15(2), 87109.

2. Giles, H., \& Smith, P. M. (1979). Accommodation theory: Optimum levels of convergence. In $\mathrm{H}$. 
Giles \& R. N. St. Clair (Eds.), Language and social psychology (pp. 45-65). Oxford, UK: Basil Blackwell.

3. Putman, W., \& Street, R. (1984). "The conception and perception of noncontent speech performance: Implications for speech accommodation theory," International Journal of the Sociology of Language, 97-114.

4. Bandura, A. (1986). Social foundations of thought and action: A social cognitive theory. Englewood Cliffs, NJ: Prentice-Hall.

5. Dragojevic, M., Gasiorek, J. \& Giles, H. (2015). Communication accommodation theory. The international encyclopedia of interpersonal communication.

6. Dragojevic, M., Gasiorek, J., \& Giles, H. (2016a). Accommodative strategies as core of the theory. In H. Giles (Ed.), Communication accommodation theory: Negotiating personal and social identities across contexts (pp. 36-59). Cambridge, UK: Cambridge University Press.

7. Gallois, C., Ogay, T., \& Giles, H. (2005). Communication accommodation theory: A look back and a look ahead. In W. Gudykunst (Ed.), Theorizing about intercultural communication (pp. 121_148). Thousand Oaks, CA: Sage.

8. Giles, H., Coupland, J., \& Coupland, N. (1991). Accommodation theory: Communication, context, and consequence. In H. Giles, J. Coupland, \& N. Coupland (Eds.), Contexts of accommodation: Developments in applied sociolinguistics (pp. 1_68). Cambridge, UK: Cambridge University Press.

9. Gasiorek, J. (2013). "I Was Impolite to Her Because That's How She Was to Me": Perceptions of Motive and Young Adults' Communicative Responses to Underaccommodation. Western Journal of Communication, 77, 604-624.

10. Bulatov, D. (2009). The effect of fundamental frequency on phonetic convergence. UC Berkeley Phonology Lab Annual Report. 404-434

11. Stupka, R. (2011). Communication Accommodation in Mixed Gender Dyads. Oshkosh Scholar. Vol. 6.

12. Pitts, M. J., \& Harwo d, J. (2015). Communication accommodation competence: The nature and nurture of accommodative resources across the lifespan. Language \& Communication, 41, 89-99

13. Giles, H., Ogay, T. (2007). Communication Accommodation Theory. Explaining Communication: Contemporary Theories and Exemplars.

14. Dragojevic, M., Gasiorek, J., \& Giles, H. (2016b). Communication accommodation theory. In C. R. Berger \& M. Roloff (Eds.), The international encyclopedia of interpersonal communication (Vol. 1, pp. 176-196). Hoboken, NJ: Wiley Blackwell.

15. Giles, H., Willemyns, M., Gallois, C., \& Anderson, M. C. (2007). Accommodating a new frontier: The context of law enforcement. In K. Fiedler (Ed.),
Social communication (pp. 129-162). New York, NY: Psychology

16. Gasiorek, J. Giles, H. (2013). Accommodation the Interactional Dynamics of Conflict Management. Iranian Journal of Society, culture \& language. 112

17. Giles, H., \& Johnson, P. (1987). Ethnolinguistic identity theory: A social psychological approach to language maintenance. International Journal of the Sociology of Language, 68, 69-99.

18. Gallois, C., Weatherall, A., \& Giles, H. (2016). CAT and talk in action. In Giles, H. (ed.). Communication accommodation theory: Negotiating personal and social identities across contexts. Cambridge, UK: Cambridge University Press, 105-122.

19. Gallois, C., \& Giles, H. (1998). Accommodating mutual influence in intergroup encounters. In M. Palmer \& G.A. Barnett (Eds.), Mutual influence in interpersonal communication: Theory and research in cognition, affect, and behavior (pp. 135-162). New York: Ablex.

20. Gasiorek, J., \& Giles, H. (2012). Effects of Inferred Motive on Evaluations of Nonaccommodative Communication. Human Communication Research, 38, 309-331

21. Beebe, L. M., \& Giles, H. (1984). Speechaccommodation theories: A discussion in terms of second-language acquisition. International Journal of the Sociology of Language, 46, 532. https://doi.org/10.1515/ijsl.1984.46.5

22. Coupland, N., \& Giles, H. (Eds). (1988). Communication acommodation: Recent advances. Language and Communication, 8.3-4.

23. Giles, H., Bourhis, R. Y., \& Taylor, D. M. (1977). Towards a theory of language in ethnic group relations. In H. Giles (Ed.), Language, ethnicity and intergroup relations. London: Academic Press.

24. Keblusek, L., Giles, H., \& Maass, A. (2017). Communication and group life: How language and symbols shape intergroup relations. Group processes \& Intergroup relations, 20(5), 632-643.

25. Giles, H., \& Soliz, J. (2015). Communication accommodation theory: A situated framework for relational, family, and intergroup dynamics. In Braithwaite, D. O. \& Schrodt, P. (eds.) Engaging theories in interpersonal communication. Multiple perspectives. Second edition. London: SAGE.

26. Giles, H. ,

\& Gasiorek, J. ( 2013 ). Intergenerational communication practices . In K.

W. Schaie \& S. Willis (Eds.), Handbook of the psychology of aging (7th ed., pp. $231-245$ ). New York, NY : Elsevier.

27. Giles, H. (2016). Communication Accomodation Theory. The international Encyclopedia of Communication Theory and Philosophy. https://doi.org/10.1002/9781118766804.wbiect056

28. Coupland, N. (1984). Accommodation at work: Some phonological data and their implications. 
International Journal of the Sociology of Language, 46, 49-70

29. McGlone, M. S., \& Giles, H. (2011). Language and interpersonal communication. In M. L. Knapp \& J. A. Daly (Eds.), The SAGE handbook of interpersonal communication (4th ed., pp. 201237). Thousand Oaks, CA: Sage.

30. Williams, J. E., Satterwhite, R. C., \& Best, D. L. (1999). Pancultural gender stereotypes revisited: The five factor model. Sex roles, 40, 513-525.

31. Giles, H., Scherer, K. R., \& Taylor, D. M. (1979). Speech markers in social interaction. In K. R. Scherer \& H. Giles (Eds.), Social markers in speech. Cambridge: Cambridge University Press.

32. Tsoumou, J. M. (2019). Comminocation Accommodation Amongst Congolese Facebook Users. HUARTE DE SAN JUAN JOURNAL. 19. 1 24.

33. Danescu-Niculescu-Mizil C, Gamon, M. Dumais, S. (2011). Mark my worlds! Linguistic style accommodation in social media. In: WWW' 11 proceedings of the 20th international conference on world wide web, Hyderabad, India

34. Gasiorek, J. (2016). Theoretical perspectives on interpersonal adjustments in language 153 and communication. In H. Giles (Ed.), Communication accommodation theory: Negotiating personal and social identities across contexts (pp. 13-35). Cambridge, UK: Cambridge University Press.

35. Gibson, A. Free speech and safe space: How moderation policies shape online discussion spaces. Social Media Society. 1-15

36. Berger, J., \& Heath, C. (2008). Who drives divergence? Identity signaling, out-group similarity, and the abandonment of cultural tastes. Journal of Personality and Social Psychology, 95(3), 593-607

37. Palomares, R. A. Hurley, D. J. Bittar, J. H. J. Saliki, J. T. Woolums, A. R. Moloere, F. Havenga, R. A. Norton, N. A. Sigmund, A. J. Barber, C. E. Berger, M. L. Clark, M. J. Fratto, M. A. (2016). Effect on injectable trace minerals on humoral and cell-mediated immune responses to Bovine viral diarrhea virus, Bovine herpes virus vaccine in dairy calves. Vest. Immunol. Immunopathols. 178, 88-98.

38. Street, R. L., \& Giles, H. (1982). Speech accommodation theory: A social cognitive model of behavior. In M. E. Roloff \& C. R. Berger (Eds.), Social cognition and communication (pp. 193-226). Beverly Hills, CA: Sage.

39. Gasiorek, J., \& Dragojevic, M. (2017). The effects of accumulated underaccommodation on perceptions of underaccommodative communication and speakers. Human Communication Research, 43, 276-294. doi:10.1111/hcre.12105

40. Bourhis, R. Y. (1984). "Cross-cultural Communication in Montreal: Two Field Studies since Bill 101." International Journal of the Sociology of Language 46: 33-47.
41. Giles, H., \& Powesland, P. F. (1975). Speech styles and social evaluation. London: Academic Press.

42. Pardo, I. D., Garman, R. H., Weber, K., Bobrowski, W. F., Hardisty, J. F., and Morton, D. (2012). Technical guide for nervous system sampling of the cynomolgus monkey for general toxicity studies. Toxicol Pathol 40, 624-36

43. Bradac, J. J., Mulac, A., \& House, A. (1988). Lexical diversity and magnitude of convergent versus divergent style shifting: perceptual and evaluative consequences. Language and Communication, 8, 213-228

44. Nelson, S., Dickson, D., \& Hargie, O. (2003). Learning together, living apart: The experiences of university students in Northern Ireland. Qualitative Studies in Education, 16(6), 777-795.

45. Van Den Berg, M. E. (1986). Language planing and language use in Taiwan: social identity, kanguage accommodation, and language choice behavior. International Journal of Society and Language. 39. 97-115.

46. Namy, Laura L., Lynne C. Nygaard, \& Denise Sauerteig. (2002). Gender differences in vocal accommodation: the role of perception. Journal of Language and Social Psychology, 21:422-432.

47. Bilous, F. R., \& Krauss, R. M. (1988). Dominance and accommodation in the conversational behaviours of same- and mixed-gender dyads. Language \& Communication, 8(3-4), 183194. https://doi.org/10.1016/0271-5309(88)90016$\mathrm{X}$

48. Argyle, M. (1969). Social Interaction. Methuen, London

49. Gardner-Chloros, P. (2009) Code-switching. Cambridge: Cambridge University Press.

50. Clark, H. H.. \& Carlson. T. B. (1982). Hearers and speech acts. Language. 58:332-73.

51. Sachdev, I., \& Bourhis, R. Y. (2001). Multilingual communication. In W. P. Robinson \& H. Giles (Eds.), The new handbook of language and social psychology (pp. 407-428). Chichester, UK: Wiley

52. Bell, A. (1984). Language style as audience design. Language in Society. 13(2). 145-204.

53. Clark, H. H., \& Brennan, S. E. (1991). Grounding in communication. In L. B. Resnick, J. M. Levine, \& S. D. Teasley (Eds.). Perspectives on socially shared cognition (pp. 127-149). Washington, DC: APA Books

54. Clark, H., \& Krych, M. A. (2004). Speaking while monitoring addressees for understanding. Journal of Memory and Language, 50, pp. 62-81

55. Clark, H. H., \& Wilkes-Gibbs, D. (1986). Referring as a collaborative process. Cognition, 22(1), 139. https://doi.org/10.1016/0010-0277(86)90010-7

56. Clark, H. H., \& Schaefer, E. F. (1989). Contributing to discourse. Cognitive Science, 13(2), 259 294. https://doi.org/10.1207/s15516709cog1302_7

57. Traum, D. R. (1994). A Computational Theory of Grounding in Natural Language Conversation (No. 
TR-545). Rochester Univ NY Dept of Computer Science.

58. Thakerar, J. N., Giles, H., \& Cheshire, J. (1982). Psychological and linguistic parameters of speech accommodation theory. In C. Fraser \& K. R. Scherer (Eds.), Advances in the social psychology of language (pp. 205-255). Cambridge, England: Cambridge University Press

59. Jefferson, G. (1980). On "trouble-premonitory" response to inquiry. Sociological Inquiry, 50(3-4), 153-185.

60. Goodwin, M. H., \& Goodwin, C. (1986). Gesture and coparticipation in the activity of searching for a word. Semiotica, 62(1-2), 51-76

61. Cohen, B., \& Murphy, G. L. (1984). Models of concepts. Cognitive Science, 8, 27- 58

62. Chartrand, T. L., \& van Baaren, R. (2009). Human mimicry. In M. P. Zanna (Ed.), Advances in experimental social psychology. Advances in experimental social psychology, Vol. 41 (p. 219274). Elsevier Academic Press.

63. Ireland, M.E., \& Pennebaker, J.W. (2010). Language style matching in writing: Synchrony in essays, correspondence, and poetry. Journal of Personality and Social Psychology, 99, 549-571.

64. Niederhoffer, K.G., \& Pennebaker, J.W. (2002). Linguistic style matching in social interaction. Journal of Language and Social Psychology, 21, 337-360

65. Pennebaker, J. W. (2011). The secret life of pronouns: What our words say about us. New York: Bloomsbury Press

66. Romero, J. R. Franceschetti, M; Bueno, E; Sesma, A. (2015). "Multilayer regulatory mechanisms control cleavage factor I proteins in filamentous fungi". Nucleic Acids Research.

67. White, C. H. (2008). Expectancy violations theory and interaction adaptation theory, from expectation to interaction. In Baxter, L. A \& Braithwaite, D. O (Eds.), Engaging theories in interpersonal communication: Multiple perspectives (pp. 189201). Thousand Oaks, CA: Sage.

68. Burgoon, J. K., \& Hubbard, A. E. (2005). Crosscultural and intercultural applications of expectancy violations theory and interaction adaptation theory. Theorizing about intercultural communication, 149-171.

69. Malle, B. F. (2004). How the Mind Explains Behavior: Folk Explanations, Meaning, and Social Interaction. Cambridge, MA: MIT Press.

70. Reeder, G. D. (2009). Mindreading: Judgments about intentionality and motives in dispositional inference. Psychological Inquiry,20 (1), 1-18

71. Hassin, R. R., Aarts, H., \& Ferguson, M. J. (2005). Automatic goal inferences. Journal of Experimental Social Psychology, 41, 129-140

72. Malle, B. F., \& Holbrook, J. (2012). Is there a hierarchy of social inferences? The likelihood and speed of inferring intentionality, mind, and personality. Journal of Personality and Social Psychology, 102, 661-84.

73. Ross, S., \& I. Shortreed (1990) "Japanese Foreigner Talk: Convergence or Divergence?". Journal of Asian Pacific Communication, 1, pp.135-146

74. Hewett, D. G., Watson, B. M., \& Gallois, C. (2015). Communication between hospital doctors: underaccommodation and interpretability. Language \& Communication, 41, 71-83. 